\title{
New species and new records of Eastern Palaearctic scythridids from the Irano-turanian Region (Lepidoptera: Gelechioidea: Scythrididae)
}

\author{
Pietro Passerin d'Entrèves \& Angela Roggero*
}

\begin{abstract}
Passerin d'Entrèves, P. \& Roggero, A. 2008: New species and new records of Eastern Palaearctic scythridids from the Irano-turanian Region (Lepidoptera: Gelechioidea: Scythrididae). — Entomol. Fennica 19: 159-167.

Four new Scythrididae species are described from the Eastern Palaearctic region. Scythris pamirica sp.n., S. balkhi sp.n., and S. brandti sp.n. were collected in North-Eastern Afghanistan, while S. elburzi sp.n. was collected in Northern Iran. The lectotype of S. paelopyga (Staudinger, 1880) is established here, and the male genitalia are described. Morphological affinities and differences of the new species are reported, and related to the scythridid taxa that are closer to them. New records of little known species from the Irano-turanian region are listed.

P. Passerin d'Entrèves, University of Torino, Department of Biologia Animale e dell'uomo, Via Accademia Albertina 13, I-10123 Torino, Italy

A. Roggero, *corresponding author, Dept. Biologia Animale e dell'Uomo, Via Accademia Albertina 13, I-10123 Torino, Italy; E-mail: angela.roggero@ unito.it
\end{abstract}

Received 17 May 2007, accepted 28 September 2007

\section{Introduction}

During the $\mathrm{XIX}^{\text {th }}$ and $\mathrm{XX}^{\text {th }}$ centuries expeditions were successively organized in the Irano-turanian Region (Lederer 1869, Brandt 1938, Wiltshire 1957). As listed in Amsel (1949a), lepidopteran material was collected by Bienert (1858-59), Haberhauer Jr. (1877-97), Wiltshire (1935-38), Brandt (1936-37) and Richter (1954-56) among others. Many new lepidopteran species were described from the area, but the results were relatively scarce for the Scythrididae (i.e., Staudinger 1880, Christoph 1885, Meyrick 1918, 1924, Amsel 1949b). More recently, further material was obtained after the Hacker Expedition in Pakistan in 1988 (Bengtsson 1997a), and the Austrian Expedition in northern Iran in 2001 (Bengtsson \&
Huemer 2003). Moreover, being very few new species identified and assigned to this family till now, the scythridid fauna of far eastern areas remains poorly studied (Passerin d'Entrèves \& Roggero 2007).

Twentynine species are recorded from various parts of Iran and Afghanistan (Table 1), but till now Scythris limbella alone was reported from both the countries (Landry 1991). Based on current knowledge of Scythrididae world distribution, we expect the fauna of Iran and Afghanistan to be far more diverse than presently known, and likely most of the species are not identified yet. We also assume that there is more or less close relationships to the fauna of surrounding central Asia (Turkmenistan, Tadjikistan, and Pakistan) and more remote areas (W Palaearctic, 
Table 1. List of the species from the study area.

\begin{tabular}{|c|c|c|}
\hline & Afghanistan & Iran \\
\hline Apostibes afghana Passerin d'Entrèves \& Roggero, 2003 & $\mathrm{X}$ & - \\
\hline Apostibes inota (Meyrick, 1924) & $x$ & - \\
\hline Catascythris kebirella Amsel 1935 & - & $\mathrm{x}$ \\
\hline Eretmocera medinella (Staudinger 1859) & - & $x$ \\
\hline Scythris apicalis (Zeller 1847) & - & $\mathrm{x}$ \\
\hline Scythris biacutella Bengtsson 2002 & - & $\mathrm{X}$ \\
\hline Scythris camelella Walsingham 1907 & _- & $\mathrm{x}$ \\
\hline Scythris canceroides Bengtsson 1997 & - & $\mathrm{X}$ \\
\hline Scythris canescens (Staudinger 1880) & $\mathrm{X}$ & - \\
\hline Scythris curlettii Bengtsson 1997 & - & $\mathrm{X}$ \\
\hline Scythris decrepidella Bengtsson 1997 & - & $\mathrm{X}$ \\
\hline Scythris ethmiella Amsel 1974 & _- & $x$ \\
\hline Scythris fissurella Bengtsson 1997 & - & $\mathrm{x}$ \\
\hline Scythris flabella (Mann 1861) & - & $x$ \\
\hline Scythris friedeli Bengtsson 1997 & - & $\mathrm{x}$ \\
\hline Scythris ghaemii Bengtsson \& Huemer 2003 & - & $\mathrm{X}$ \\
\hline Scythris herati Passerin d'Entrèves \& Roggero 2004 & $\mathrm{x}$ & - \\
\hline Scythris limbella (Fabricius 1775) & $\mathrm{x}$ & $\mathrm{x}$ \\
\hline Scythris monochreella (Ragonot 1896) & - & $\mathrm{X}$ \\
\hline Scythris mus Walsingham 1898 & - & $\mathrm{X}$ \\
\hline Scythris nielseni Passerin d'Entrèves \& Roggero 2004 & $\mathrm{X}$ & - \\
\hline Scythris pangalactis Meyrick 1933 & - & $\mathrm{x}$ \\
\hline Scythris satyrella (Staudinger 1880) & - & $x$ \\
\hline Scythris senecai Bengtsson 1997 & - & $\mathrm{x}$ \\
\hline Scythris sinuosella Bengtsson 2002 & - & $\mathrm{x}$ \\
\hline Scythris subclavella (Rebel 1901) & - & $\mathrm{X}$ \\
\hline Scythris subparachalca Bengtsson 2002 & - & $\mathrm{X}$ \\
\hline Scythris tessulatella Rebel 1903 & - & $x$ \\
\hline Scythris valgella Bengtsson 2002 & - & $\mathrm{x}$ \\
\hline
\end{tabular}

Arabian Peninsula, Afrotropical Region, India) as is known for many other taxa (Larsen 1984, Akhani et al. 1997, Macey et al. 1998, Ribera \& Blasco-Zumeta 1998, Sruoga \& Puplesiené 1998, Çiplak 2003, Frisch 2006, Mey 2006, Nabozhenko 2006).

The aim of the present work is to describe four new species of Irano-turanian Scythrididae and to update the knowledge of the family by presenting new distributional data on a number of other species.

\section{Material and methods}

We examined typical and not-typical material from Iran and Afghanistan preserved in many institutional and private collections. To identify specimens, genitalia features were employed as usually proposed in literature (Bengtsson 1997b). The preparation of genitalia followed the standard procedure (Landry 1991, Bengtsson 1997b), but mounting followed the method described by Passerin d'Entrèves (1976) for Scythrididae male genitalia in order to avoid flattening and distorting of parts.

Four new species from Irano-turanian Region were identified (Fig. 1), and are described here. The type materials of the four new species are deposited in Staatliche Museum für Naturkunde of Karlsruhe (SMNK, Germany), Museum für Naturkunde der Humboldt-Universität of Berlin (MNHB, Germany) and Naturhistoriska Riksmuseet of Stockholm (NHRM, Sweden).

In this paper we followed the traditional classification, in which scythridids are ranked at family level (Nye \& Fletcher 1991, Kaila 2004), rejecting at present the taxonomy proposed by 
Fig. 1. Type localities of the four new scythridid species: S. elburzi sp.n. (1), S. balkhi sp.n. (2), S. pamirica sp.n. (3) and S. brandti sp.n. (4).

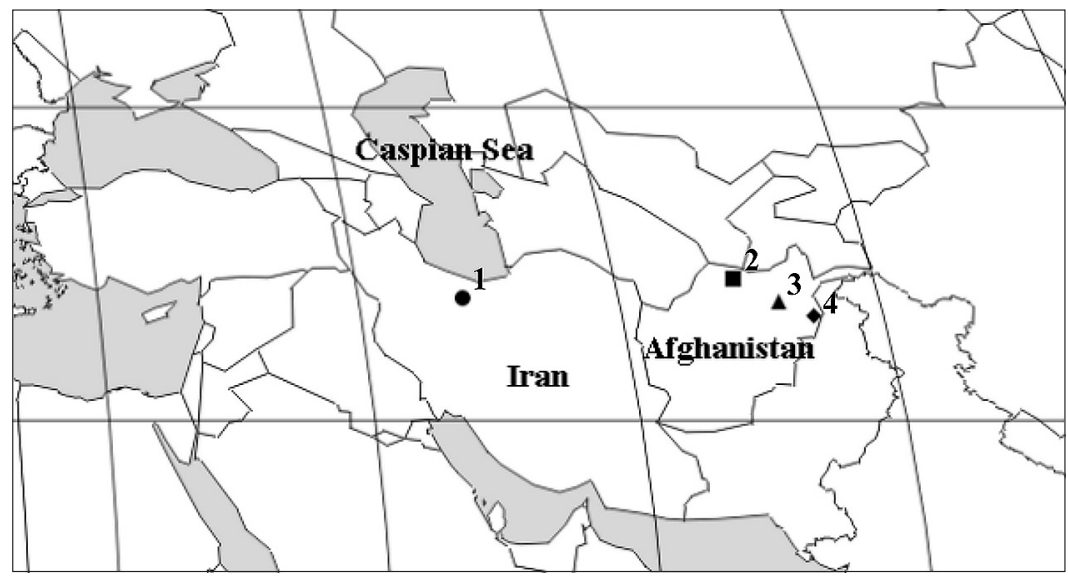

Hodges (1998) who lowered the scythridid status to subfamily level (in Xylorictidae family).

\section{New species}

\subsection{Scythris pamirica sp. $\mathrm{n}$.}

Type material. Holotype: đ̊ (Fig. 2a): NO[st] Afghanistan, Khinch-e-Andarab, westl. Pamir, 3,550-4,000 m a.s.1., G. Ebert leg., 17.-27.VII. 1957. Genital Slide 288 ZMB (MNHB).

Diagnosis. The species is externally similar to many other scythridids and can be identified only by examination of genitalia. On the basis of the male genitalia the similarity with $S$. satyrella (Staudinger, 1880) is evident. Main diagnostic characters for the species are the laminar uncus and the well-developed, spatulate valvae.

Description. Wingspan $20 \mathrm{~mm}$. Forewing brown, with apex very dark brown and a narrow, whitish line subapically at costal margin, one third long as wing; two whitish patches in middle of wing surface: one long and Y-shaped, extended to two thirds of wing, the second rounded at cell end. Fringe brownish, darker near apex. Hindwings greyish, glossy. Fringe long, light brown. Head, thorax and abdomen brown. Legs pale brown. Antenna brown, three-fourths length of forewing.

Male genitalia (Fig. 3a-c). Uncus Y-shaped, distal arms very short and rounded; gnathos as long as vinculum, laminar, asymmetrical, with tapered and apically pointed distal arm. Valvae symmetrical, spatulate, with narrow proximal third. Vinculum one third long as valvae, distal margin rounded. Aedeagus almost as long as valvae, tubular and down-turned, with distal half sigmoid and abruptly narrowing toward apex; juxta short and pyriform. Sternum VIII subtriangular, as long as valvae, bifid at apex, apices diverging, carrying two small processes at distal third, the proximal margin with deep, arched notch and two thickened articular plicae on sides.
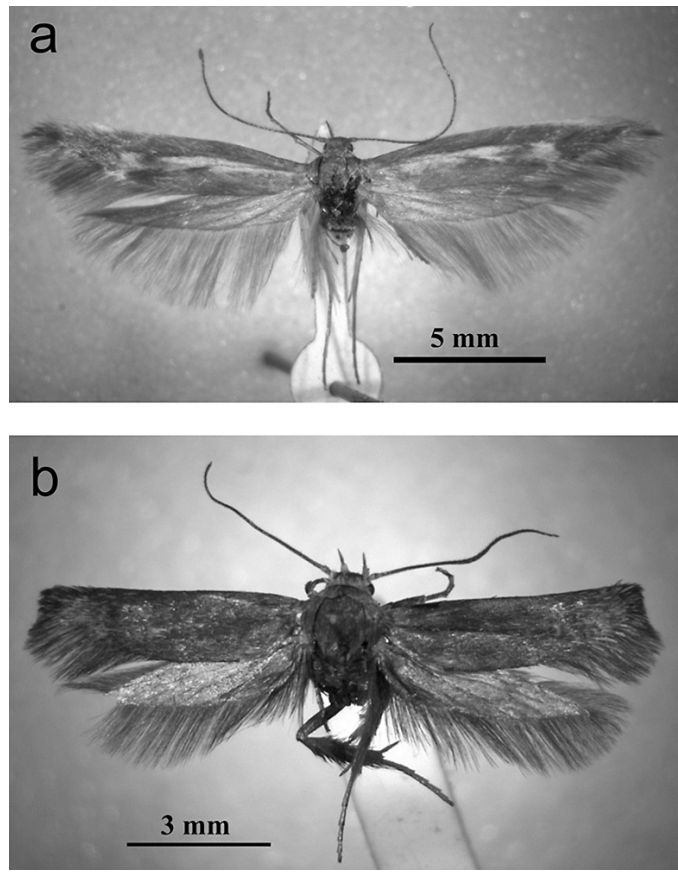

Fig. 2. - a. S. pamirica sp.n. male (Scale bar $=5 \mathrm{~mm}$ ). -b. S. elburzi sp.n. male (Scale bar $=3 \mathrm{~mm}$ ). 

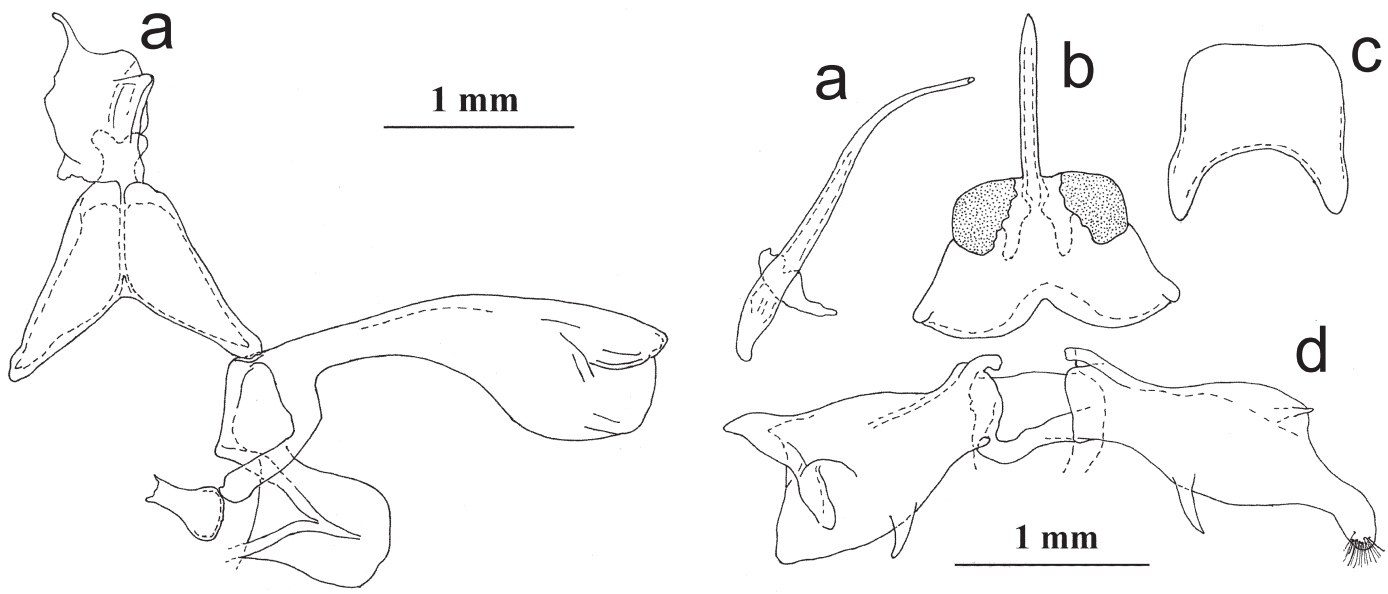
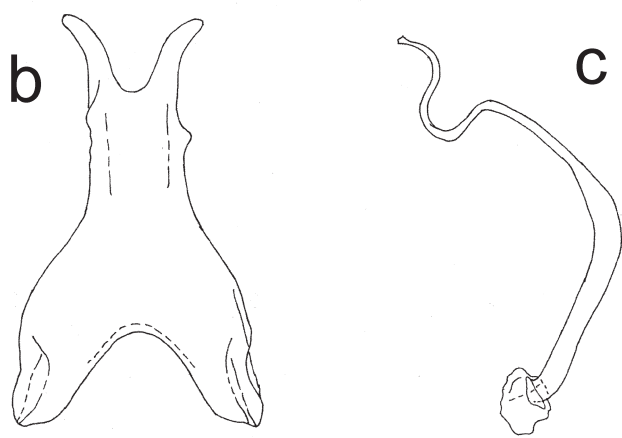

Fig. 3. S. pamirica sp.n., male genitalia. - a. Uncusgnathos-tegumen-juxta-right valva-vinculum complex. -b. VIII Sternite. - c. Aedeagus. Scale bar $=1 \mathrm{~mm}$.

Female genitalia. Unknown.

Bionomy. The species was collected in July at high elevation, in an area characterized by alpine vegetation. Host plants are unknown.

Distribution. Only known from the Pamir Range in northern Afghanistan.

Etymology. The species is named after the Pamir area, in Central Asia.

Remarks. The species has a close resemblance to $S$. satyrella described from Iran (Shahrud) and Turkmenistan (Ashkrabad and Nukhur, AchalTekke region), although Bengtsson quoted it also from Turkey (1997b:62) and Russia (from Sarepta; 1997b: 223). Likely, the two species belong to the same species-group. They are separated on the basis of the marked difference in features of valvae and sternum VIII and different length of the aedeagus, the uncus-gnathos-tegumen complex being similar. It must be noted that

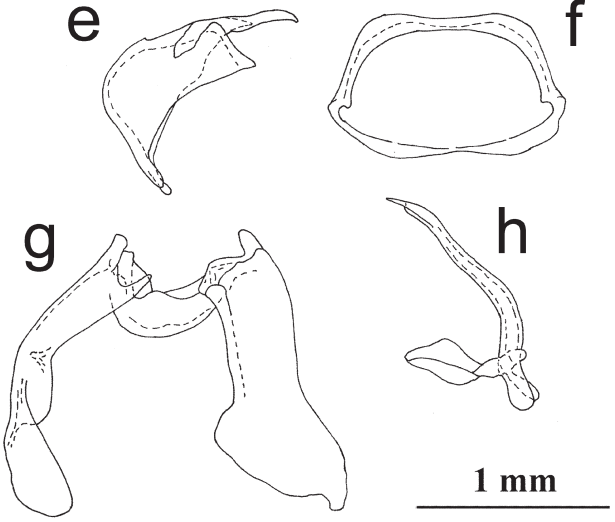

Fig. 4. S. elburzi sp.n., male genitalia. - a. Aedeagus - b. Uncus-tegumen complex. - c. VIII Sternite. - d. Valvae and vinculum. Scale bar $=1 \mathrm{~mm}$. S. paelopyga (Staudinger, 1880), male genitalia. - e. Uncus-tegumen complex. - f. VIII Sternite. - g. Valvae and vinculum. $-\mathrm{h}$. Aedeagus. Scale bar $=1 \mathrm{~mm}$.

in the description of $S$. satyrella genitalia, Bengtsson (1997b: 62) perhaps mistook the gnathos for the uncus.

We hypothesized that $S$. pamirica and $S$. satyrella are both more likely related to the palaearctic than to afrotropical and oriental scythridid fauna. In order to find other specimens belonging to the same species-group, we are now examining scythridid collections from the same area to analyze their phylogenetic relationships.

\subsection{Scythris elburzi sp. n.}

Type material. Holotype: $\hat{o}$ (Fig. 2b): Iran, 
Table 2. A comparison of Scythris paelopyga (Staudinger) and S. elburzi sp.n.

\begin{tabular}{|c|c|c|}
\hline Structure & S. paelopyga & S. elburzi \\
\hline Uncus & $\begin{array}{l}\text { Short, half as long as the tegumen, sharp, } \\
\text { narrow and thorn-like }\end{array}$ & $\begin{array}{l}\text { Very long, needle-like, with a globular } \\
\text { expansion near the base }\end{array}$ \\
\hline Gnathos & Absent & Absent \\
\hline Tegumen & $\begin{array}{l}\text { Symmetrical, globose, short, with two } \\
\text { triangular laminae at superior margin }\end{array}$ & $\begin{array}{l}\text { Symmetrical, bilobed, short and large, with } \\
\text { two quadrangular plates at superior margin }\end{array}$ \\
\hline Juxta & $\begin{array}{l}\text { Shell-shaped, concave, with a finger-like } \\
\text { process posteriorly }\end{array}$ & Shell-shaped, smaller than in S. paelopyga \\
\hline Aedeagus & Bisinuate, narrowing to apex & Rectilinear, downturned at two thirds of length \\
\hline Valvae & $\begin{array}{l}\text { Asymmetrical, the right valva rectilinear } \\
\text { with a tootlike process inward turned at } \\
\text { apex, the left valva inward turned }\end{array}$ & $\begin{array}{l}\text { Asymmetrical, the right valva with a } \\
\text { fingerlike process rectilinear at apex, the } \\
\text { left valva triangular shaped, with two } \\
\text { sharp vertices }\end{array}$ \\
\hline Vinculur & Very short, margin rounded & Very short, margin bisinuate \\
\hline Sternum VIII & $\begin{array}{l}\text { Rectangular, short, only slightly notched in } \\
\text { the middle at hind edge }\end{array}$ & $\begin{array}{l}\text { Quadrangular, hind margin with a large V- } \\
\text { shaped notch, and fore margin carrying } \\
\text { a notch twice deeper than the hind one }\end{array}$ \\
\hline Tergum VIII & $\begin{array}{l}\text { Largely subtrapezoidal, hind margin with } \\
\text { a deep, triangular notch, with weakly } \\
\text { sclerotized lateral bulges }\end{array}$ & Quadrangular, the fore angles rounded \\
\hline
\end{tabular}

Elbursgebirge Kerodj (= Keredji, now Karaj), Brandt leg., 20.VI.1936. Genital Slide 1105 PdE (NHRM).

Diagnosis. The species can be identified only by examination of the genitalia, diagnostic characters being the long and sharp uncus, and the asymmetrical valvae.

Description. Wingspan $16 \mathrm{~mm}$. Forewings evenly dark brown, fringe brown. Hindwings very light brown, glossy, fringe brownish. Head, thorax and abdomen dark brown. Legs dark brown, with dense, thick and dark brown vestiture. Antennae dark brown, two thirds long as forewings.

Male genitalia (Fig. 4a-d). Uncus longer than tegumen, narrow, sharp, pointed, with bulge at base. Gnathos absent. Tegumen very short, subtriangular, with two rectangular laminae at distal edge, extending upward. Valvae asymmetrical, fused at proximal margin; middle of inner margin with down-turned, thorn-shaped process, similar in both valvae; proximal margin of both valvae with inwardly arched, short and thick process; left valva two-thirds as long as right one, triangularly shaped; right valva twice as long as wide, narrowing to apex, finger-like and inwardly turned, with tuft of long setae and triangular, small lamina on outer side. Vinculum very short, bilobed. Aedeagus cylindrical, down-arched, blunt, narrowing at apex, longer than valvae. Tergum VIII (not drawn) quadrangular, distal margin rounded, slightly notched; sternum VIII quadrangular, bilobed, with large V-shaped notch at distal margin, and twice deeper notch at proximal margin.

Female genitalia. Unknown.

Bionomy. The species was collected in a mountainous area at an unspecified elevation. Host plants are unknown.

Distribution. Known only from Northern Iran.

Etymology. The species is named after the Elburz Range, where the type locality is situated.

Remarks. The species is similar to S. paelopyga (Staudinger, 1880) from Amasya, Turkey (Fig. 4). The two species can be easily separated on genital differences (Table 2). For further details, see the genitalia description of S. paelopyga below.

The distribution of both $S$. elburzi sp.n. and $S$. paelopyga shows that the species are related to palaearctic fauna more than to afrotropical and oriental ones. Palaearctic species are relatively common in Iran, which is part of a transitional zone between Palaearctic, Afrotropical and Oriental Regions (Frisch 2006). 

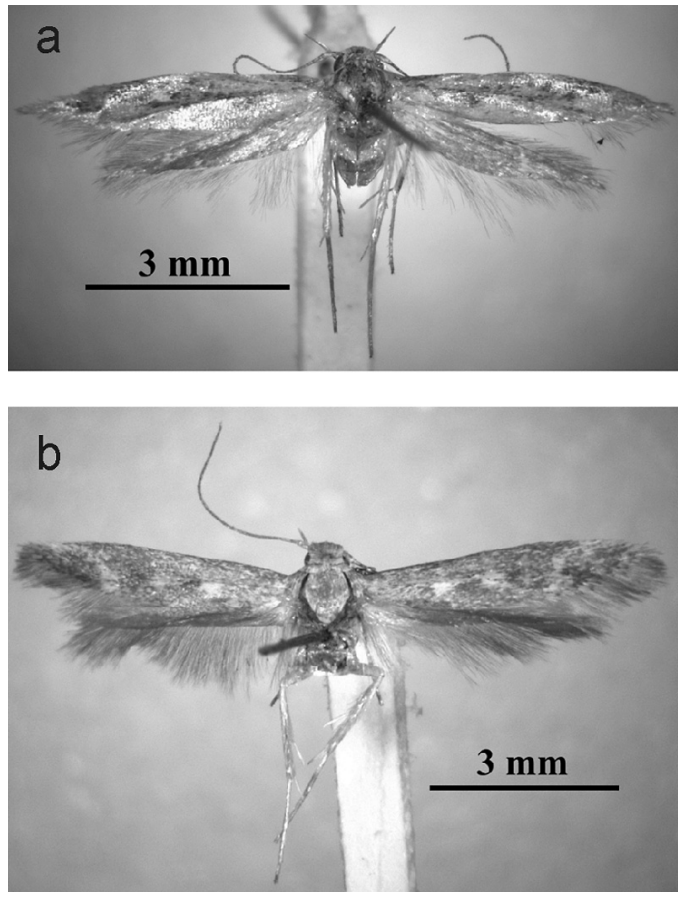

Fig. 5. - a. S. balkhi sp.n. male (Scale bar $=3 \mathrm{~mm}$ ). -b. S. brandti sp.n. male (Scale bar $=3 \mathrm{~mm}$ ).

\subsection{Scythris balkhi sp. n.}

Type material. Holotype: $\widehat{\jmath}$ (Fig. 5a): N Afghanistan, Balkh, $400 \mathrm{~m}$ a.s.1., H. G. Amsel leg., 24.V. 1956. Genital Slide 836 PdE (SMNK).

Diagnosis. Easily confused with other species from the Irano-turanian Region on the basis of external features alone, this species has distinct genitalia, with valvae very reduced and the aedeagus sickle-shaped.

Description. Wingspan $9 \mathrm{~mm}$. Forewings whitish with two light brown dots near apex. Fringe brownish. Hindwings and fringe very light brown. Head, thorax and abdomen light brown. Legs light brown. Antenna brown, almost as long as forewing, with antennal scape whitish.

Male genitalia (Fig. 6a, b). Uncus elongate, bifid, with deep incisure. Gnathos well-developed, with joining arms narrow and elongate, distal arm cylindrical, as long as uncus, slightly down-turned. Tegumen globose. Valvae symmetrical, reduced, rounded at apex, fused to tegumen. Vinculum very small. Aedeagus shorter than uncus, superior margin bisinuate, upward-turned with sharp apex. Juxta short and upturned.
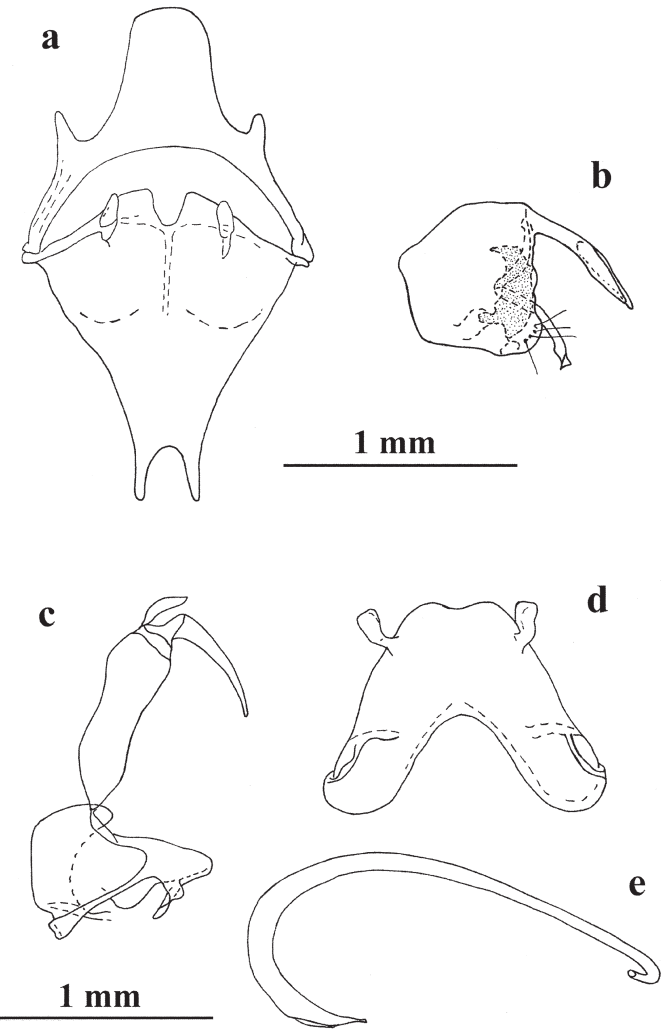

Fig. 6. S. balkhi sp.n., male genitalia. - a. VIII Tergite and sternite. $-b$. Uncus-tegumen-gnathos-aedeagusvalva complex, side view. Scale bar $=1 \mathrm{~mm}$. $S$. brandti sp.n., male genitalia. - c. Uncus-tegumengnathos-valva complex, side view. - d. VIII Sternite; e. Aedeagus. Scale bar $=1 \mathrm{~mm}$.

Tergum VIII subtriangular, distally rounded, with well-developed extrusion at outer side, with deeply arched, thickened base, joined to sternum VIII. Sternum VIII subtriangular, with two short, parallel prongs at apex, and narrow, triangular notch in middle of thickened proximal margin.

Female genitalia. Unknown.

Bionomy. The species was collected in May at low elevation. Host plants unknown.

Distribution. Known only from northern Afghanistan.

Etymology. The species is named after the type locality, Balkh, in northern Afghanistan. It is the oldest town in Afghanistan, and was known in the past as Bactra.

Remarks. The species very likely does not belong to any known species-group, but the shape of sternum VIII indicates that the new species 
might be related to the $S$. subfasciata-group of species (K. Nupponen, pers. comm.), or S. musgroup of species. The type locality lies in a plain at the foothills of the Eastern Hindu Kush Range, where these mountains lead in the Pamir.

\subsection{Scythris brandti sp. $\mathrm{n}$.}

Type material. Holotype: $\lesssim$ (Fig. 5b): N Afghanistan, Hindukusch Doab, 1,400 m a.s.1., H. G. Amsel leg., 4.VI.1956. Genital Slide 829 PdE (SMNK).

Diagnosis. The species cannot be recognized on the basis of external appearance, but is easily identified from its genitalia: sternum VIII with two prolongations near the hind margin, and the fishhook-like aedeagus are unique. Also the valvae and the complex uncus-gnathos-tegumen are well-characterized.

Description. Wingspan $10 \mathrm{~mm}$. Forewings light brown, with two white irregular patches and transverse white line at distal third, fringe brown. Hindwing brown with brown fringe. Head, thorax and abdomen brownish. Legs very light brown. Antenna light brown, almost as long as forewing.

Male genitalia (Fig. 6c-e). Uncus laminar, dome-like. Gnathos with triangular median process, very long and downward curved. Tegumen narrow, as long as the valvae. Valvae symmetrical, small, triangular, proximal margin rounded and apex blunt; inner margin inwardly curved with spiniform process near apex at inner margin. Aedeagus three times longer as valvae, narrow, strongly curved at basal half, tip hooked. Juxta long. Sternum VIII subtriangular, distally truncated and slightly emarginate, base thickened and deeply notched, two triangular lateral processes at distal third.

Female genitalia. Unknown.

Bionomy. The species was collected in early June in the Hindu Kush Range, at relatively low elevation. Host plants and life cycle are unknown.

Distribution. Known only from northern Afghanistan.

Etymology. The species is named after Dr. Brandt, who made expeditions in Iran and collected many interesting Lepidoptera from that region.
Remarks. The species does not seem to belong to any know species-group.

\section{Description of male genitalia of Scythris paelopyga (Staudinger, 1880)}

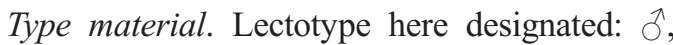
Turkey, Amasya. "25/7”, “Amasia M", “Origin”, "Paelopyga", "Prep. Gen. 1365 PdE", "Lectotypus Butalis paelopyga (Stgr.) Passerin \& Roggero 2007”. Genital Slide 1365 PdE (MNHB).

Diagnosis. The species is similar to many other scythridids, but the asymmetrical valvae, the tegumen with two triangular expansions and the aedeagus are useful diagnostic characters for the species.

Description. The external features of $S$. paelopyga were exaustively described by Staudinger (1880), but the author did not elucidate the characteristic shape of the genitalia. Here, we present the drawing and description of the male genitalia.

Male genitalia (Fig. 4e-h). Uncus narrow, thorn-shaped, sharp at apex, half long as tegumen. Gnathos absent. Tegumen globular, carrying at distal edge two asymmetrical, triangular laminae with sharp apices upward and outward extending. Valvae asymmetrical: left valva rectilinear, with blunt tooth inwardly turned at external apex, and triangular lamina extending at distal half of inner margin; right valva narrower than left one, inwardly turned, apex rounded and spatular, oval lamina at middle of inner margin; vinculum short and rounded. Aedeagus bisinuate, larger at base and tapered toward apex. Juxta half as long as aedeagus, triangular, concave. Sternum VIII rectangular, hind margin rounded and slightly notched in the middle. Tergum VIII subtrapezoidal, posterior margin deeply and narrowly notched, with weakly sclerotized lateral bulges.

Bionomy. The species was collected from April to August (Staudinger 1880).

Distribution. Known in the past only from Amasya (Turkey), the species was collected recently in Aksehir, Sultan Daglari (Central Turkey) by K. Nupponen at the beginning of August; the habitat is a xerothermic, chalk slope; the moth 
is nocturnal and come readily to artificial light at night (K. Nupponen, pers. comm.).

Remarks. Likely the species belongs to the same species-group as $S$. elburzi sp.n. Staudinger collected four male specimens in his Turkish Expedition during 1875 (the lectotype and three others in the same locality as the lectotype, 10.V., 3.VI. and 1.VIII.1875); two other male specimens were collected from Amasya on 26.IV.1875 by J. Mann, who gave them to the author, as reported by Staudinger (1880: 391), who also pointed out that one of them was damaged.

\section{New records}

Apostibes griseolineata Walsingham, 1907

Afghanistan, Herat, 970 m a.s.1., 5.V.1956, H. G. Amsel leg., 1 § [Genital Slide 816 PdE].

Distribution. Algeria, Tunisia, Libya, and Israel.

Remarks. New to Afghanistan. Herat (W Afghanistan) is located in the fertile valley of Hari Rud River.

Scythris canescens (Staudinger, 1880)

N. Afghanistan, Polichomri, $700 \mathrm{~m}$ a.s.1., 5.VI.1956, H. G. Amsel leg., 5 ठิ slides 810, 813, 838, 839 and 844 PdE].

Distribution. Morocco, Algeria, Tunisia, Libya, Turkey, Syria, Afghanistan, and Pakistan.

Remarks. Pol-e-Khomri (Baghlan Province) is located in the NE Afghanistan, near the Hindu Kush Range.

Scythris capitalis (Erschoff, 1874)

$\mathrm{NO}$ [st] Afghanistan, Khinch-e-Andarab, westl. Pamir, 3,550-4,000 $\mathrm{m}$ a.s.1., 17.27.VII.1957, G. Ebert leg., $3 \precsim \widehat{\jmath}$ [Genital slides

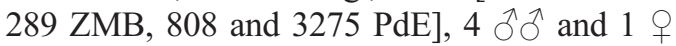
[Genital slide 3276 PdE].

Distribution. Turkey, Turkmenistan, Tajikistan, Uzbekistan, and Kyrgyzstan.

Remarks. New to Afghanistan.

Scythris decrepidella Bengtsson, 1997

Iran, Belutschistan, Jranshar, $800 \mathrm{~m}$ a.s.1., 11.-21.IV.1954, Richter u. Schäuffele leg., 1 ऽ [Genital slide 819 PdE].

Distribution. Egypt and southern Iran.
Remarks. The Baluchestan constitutes the southern part of the Sistan and Baluchestan Province, and is located in the southeast of Iran, bordering Pakistan and Afghanistan. It is characterized by a desert climate and is one of the driest regions of the country.

Scythris fissurella Bengtsson, 1997

$\mathrm{O}$ [st] Afghanistan, Sarobi, 1,100 m a.s.1., 3.VII.1956, H. G. Amsel leg., 1 ð [Genital slide $806 \mathrm{PdE}]$. O[st] Afghanistan, Sarobi, 1,100 m a.s.1., 28.VI.1956, H. G. Amsel leg., 1 \& [Genital slide $854 \mathrm{PdE}]$.

Distribution. Sudan, Yemen, Oman, Iran, Pakistan and southern Russia (K. Nupponen, pers. comm.).

Remarks. New to Afghanistan. Sarowbi (Surobay) is placed in the Kabul Province, at low elevation near the Hindu Kush Range, in NE Afghanistan.

Scythris limbella (Fabricius, 1775)

N Iran, Masandaran, Golestan-Wald, 60 km E Ganbad Qabus [=Gonbad-e Kavus, Golestan], $510 \mathrm{~m}$ a.s.1., Ebert \& Falkner leg., 8.VII.1972, 1 $\widehat{\sigma}$ [Genital Slide $374 \mathrm{PdE}$ ]. Afghanistan, Herat, 970 m a.s.1., 25.IV.1956, H. G. Amsel leg., 1 ภ [Genital Slide 835 PdE].

Distribution. Over most of Europe to Central Asia. The species is also introduced in the northeastern Nearctic Region.

Remarks. The species was already known from Iran and Afghanistan. Golestan Province (NE Iran, south of the Caspian Sea) was separated from the province of Mazandaran only in 1997.

Scythris monochreella (Ragonot, 1896)

$\mathrm{SO}$ [st] Iran, (Djiroft), Anbar-Abad, 1.18.V.1956, W. Richter leg., 1 ふ [Genital slide 842 PdE].

Distribution. Turkey, Syria, Lebanon, Israel, Egypt, United Arab Emirates, Iran, Iraq, and India.

Remarks. Anbar-Abad is located near Jiroft, in the south of Kerman Province, most of which is largely steppe or sandy desert, with scattered oases.

Scythris tributella (Zeller, 1847)

N Iran, Masandaran, Golestan-Wald, 60 km E 
Ganbad Qabus, 510 m a.s.1., Ebert \& Falkner leg.,

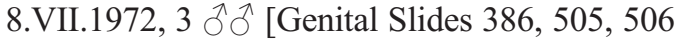
PdE].

Distribution. Europe, from Spain to Greece, Russia (S Urals), and Libya

Remarks. New to Iran.

Acknowledgements. The research was supported by the grants from the italian Ministero della Ricerca Scientifica e Tecnologica (MURST 60\% "Biosistematica dei Lepidotteri Scythrididae"). We are very grateful to Dr. H. G. Amsel ( $\dagger$ ) (Staatliche Museum für Naturkunde of Karlsruhe, Germany), and to the Curators of Entomology Collections of the Museum für Naturkunde der HumboldtUniversität of Berlin (Germany) and the Naturhistoriska Riksmuseet of Stockholm (Sweden) for the loan of the material. We would also thank Dr. W. Mey (Museum für Naturkunde der Humboldt-Universität of Berlin, Germany) for the loan of S. paelopyga type material, and Dr. B. $\AA$. Bengtsson for his useful comments. We are greatly obliged to Dr. K. Nupponen for his information about Irano-turanian scythridids.

\section{References}

Amsel, H. G. 1949a: Die Microlepidopteren der Brandt'schen Iran-Ausbeute. 1. - Bull. Soc. Fouad. I. Entomol. 33: 227-269.

Amsel, H. G. 1949b: On the Microlepidoptera collected by E. P. Wiltshire in Irak, and Iran in the years 1935 to 1938. - Bull. Soc. Fouad. I. Entomol. 33: 271-351.

Akhani, H., Trimborn, P. \& Ziegler, H. 1997: Photosynthetic pathways in Chenopodiaceae from Africa, Asia and Europe with their ecological, phytogeographical and taxonomical importance. - Pl. Syst. Evol. 206: 187221.

Bengtsson, B. Å. 1997a: Scythridids founds by H. Hacker in Pakistan 1988, and India 1992. _ Esperiana 4: 467481.

Bengtsson, B. Å. 1997b: Scythrididae. Microlepidoptera of Europe. Vol. 2. - Apollo Books, Stenstrup. 301 pp.

Bengtsson, B. Å. \& Huemer, P. 2003: Eine neue Art der Familie Scythrididae aus dem Iran (Lepidoptera, Scythrididae). — Carinthia II 193/113: 573-578.

Brandt, W. 1938: Beitrag zur Lepidopteren-Fauna von Iran. - Entomol. Rdsch. 55: 698-699.

Christoph, H. 1885: Lepidoptera aus dem Achal-TekkeGebiet. 2. Teil. — In: N. M. Romanoff. Mémoires sur les Lépidoptères. St. Petersburg. 2:119-171.

Çiplak, B. 2003: Distribution of Tettigoniinae (Orthoptera, Tettigoniidae) bush-crickets in Turkey: the importance of the Anatolian Taurus Mountains in biodiversity and implications for conservation. - Biodiversity and Conservation 12: 47-64.

Frisch, J. 2006: The genus Scopaeus (Coleoptera, Staphylinidae, Paederinae) in Iran, with description of new species from the Zagros Mountains. - Dt. Entomol. Zeit. 53: 5-22.
Hodges, R. W. 1998: Gelechioidea. - In: Kristensen, N. P. (ed.), Lepidoptera, Moths and Butterflies. Vol 1. Handbuch der Zoologie/Handbook of Zoology [Walter de Gruyter, Berlin \& New York], IV/35: 131-158.

Kaila, L. 2004: Phylogeny of the superfamily Gelechioidea (Lepidoptera: Ditrysia): an exemplar approach. Cladistics 20: 303-340.

Landry, J.-F. 1991: Systematics of Nearctic Scythrididae (Lepidoptera: Gelechioidea): phylogeny and classification of supraspecific taxa, with a review of described species. - Mem. Entomol. Soc. Canada 160: 1-341.

Larsen, T. B. 1984: The Zoogeographical Composition and distribution of the Arabian Butterflies (Lepidoptera; Rhopalocera). - J. Biogeogr. 11: 119-158.

Lederer, J. 1869: Verzeichnis der von Herrn Jos. Haberhauer bei Astrabad in Persian gesammelten Schmetterlinge. - Horae Soc. Entomol. Ross. 6: 73-93.

Macey, J. R., Schulte II, J. A., Ananjeva N. B., Larson A., Rastegar-Pouyani N., Shammakov S. M. \& Papenfuss T. J. 1998: Phylogenetic Relationships among Agamid Lizards of the Laudakia caucasia Species Group: Testing Hypotheses of Biogeographic Fragmentation and an Area Cladogram for the Iranian Plateau. - Mol. Phylogenet. Evol. 10: 118-131.

Mey, W. 2006: Revision of the genus Phyllobrostis Staudinger, 1859 (Lepidoptera, Lyonetiidae). — Dt. Entomol. Zeit. 53: 114-147.

Meyrick, E. 1918: Exotic Microlepidoptera II (19161923). — Classey, Hampton. 640 pp.

Meyrick, E. 1924: Exotic Microlepidoptera III (19231930). - Classey, Hampton. 640 pp.

Nabozhenko, M. V. 2006: A revision of the genus Catomus Allard, 1876 and the allied genera (Coleoptera, Tenebrionidae) from the Caucasus, Middle Asia, and China. - Entomol. Rev. 86: 1024-1072.

Nye, I. W. B. \& Fletcher, D. S. 1991: The generic Names of Moths of the World. Volume 6. Microlepidoptera. Natural History Museum Publication, London. 368pp.

Passerin d'Entrèves, P. 1976: Revisione degli Scitrididi (Lepidoptera, Scythrididae) paleartici. II. I tipi di Scythris del Muséum National d'Histoire Naturelle di Parigi. — Boll. Mus. Zool. Univ. Torino 1976: 27-70.

Passerin d'Entrèves, P. \& Roggero, A. 2007: Scythrididae. Fascicle 44. - In: Heppner, J. B. (ed.), Lepidopterorum Catalogus (New Series) Vol 3. Association for Tropical Lepidoptera, Gainesville. 86 pp.

Ribera, I. \& Blasco-Zumeta, J. 1998: Biogeographical links between steppe insects in the Moneagros region (Aragón, NE Spain); the Eastern Mediterranean, and Central Asia. — J. Biogeogr. 25: 969-986.

Sruoga, V. \& Puplesiené, J. 1998: Contribution to the knowledge of Central asiatic Microlepidoptera with description of new species. - Acta Zoologica Lituanica Entomologia 8: 38-48.

Staudinger, O. 1880: Lepidopteren-Fauna Kleinasien's. Horae Soc. Entomol. Ross. 15: 159-435.

Wiltshire, E. P. 1957: The Lepidoptera of Iraq. — Ministry of Agricolture, Government of Iraq. Kaye Limited, London. 162 pp. 